\title{
International, collaborative and online education of LIS-students - a step to the future?
}

\author{
Eliane Blumer ${ }^{1}$, Markus Hennies ${ }^{2}$, René Schneider ${ }^{1}$ \\ ${ }^{1}$ Haute Ecole de Gestion, 7, route de Drize, CH-1227 Carouge. E-mail: \\ \{First Name.Last Name\}@,hesge.ch \\ ${ }^{2}$ Stuttgart Media University, Nobelstr. 10, 70569 Stuttgart, Germany. Email: \\ hennies@,hdm-stuttgart.de
}

\begin{abstract}
In this paper, we will analyze and discuss the quality of a project course with an international, collaborative and online format, whose content touches all Swiss information literacy standards. The analysis on a micro-level shall illuminate if the course setup can be declared as a more comprehensive teaching method for LIS students, than the simple teacher- or classroom centered education.
\end{abstract}

Keywords: Education of Library and Information Science Students, Qualitative Evaluation, International Education, Collaborative Learning, Project Course, New Learning Methods

\section{Introduction}

If we take a look at the latest pedagogical research, it says that the traditionally acknowledged, teacher-centered education cannot prepare the new generation for the exigencies of this modern society, we are living in, anymore (Ohidy, 2009; Nagy, 2005). Movements like increasing multiculturalism, globalization and technological progress have an impact on educational methods and are transforming with high speed the already mentioned traditional education within the four walls of a classroom, which was very well-known only a couple of years ago (Stepanyan, Mather, Dalrymple, 2013). As one example of the ongoing changes, which the educational system is currently experiencing, the exponential growth of online learning programs could be mentioned (Allen, Seaman, 2007). Not to forget, it is becoming also more and more important in our society to be able to work, produce and solve problems in a team (Johnson, Johnson, 1999, 2004).

Therefore, a student ${ }^{1}$ of today has to be taught how to interact and solve problems with others, and if possible, in a multicultural context. This includes communication in more than one language and probably at distance, by using for example new communication and information technologies.

Solutions to this new educational challenge can be found in cooperative and collaborative learning methods, and by applying them to an online context. As Damon

\footnotetext{
${ }^{1}$ Any student can be concerned, in this case, it refers generally to LIS-students.
} 
and Phelps (1981) described, cooperative learning methods include all forms of team based learning approaches, and are coming out of constructive learning theory. By working in teams, discussing a topic and solving tasks together, every student brings his/her own competences and can at the same time make use of those of his/her colleagues.

Studies, such as the one of Mergendoller, Bellisimo and Maxwell (2000) have shown that collaboration, as well as the discussion of a problem and the proposal of solutions within a group exchange process, improves learner's performance.

In this context and with the idea to prepare their students to be more adaptable to the high exigencies, such as lifelong learning, a high level of comprehensive digital media and information literacy, and all this within a multicultural context, the Hochschule der Medien in Stuttgart and the Geneva School of Business Administration in Geneva organize for the 3rd time a joint semester course in the second year of their Bachelor curriculum in Information Science.

\section{The course structure}

The concerned course has been conducted from end of September 2013 until middle of December 2013 (in total 12 weeks) in collaboration of the two schools, HDM Stuttgart and the HEG Geneva for the 3rd time in the second year of the Bachelor curriculum. The participating students meet firstly in person and form mixed virtual teams (6 teams of 2, one participant from each school). The teams select then their research topics from current issues of the library and media industries and get introduced to the use of communication and collaboration tools as well as the platform where the final outcomes have to be synthetically presented. An additional social program with dinner and a one-day excursion eases the students to get in touch and overcome language barriers. An eight week intense working phase follows, in which the students choose and use the various kinds of communication and collaboration tools on their own to coordinate the project's progress from their home institutions. Eventually, the virtual teams summarize and visualize their research results on a common dashboard platform. A final workshop is held at the second university where each team presents its research results and the dashboard's specific functionality in regard to their outcomes.

By organizing the course this way, a comprehensive course has been established whose content touches all Swiss information literacy standards. After having chosen a research topic, students have to analyze their information need, retrieve corresponding information, asses and organize it, or restart the cycle continuously, together with their group members. As the final product is a compilation of their encountered resources in different formats on a dashboard platform, they are driven to directly apply and synthesize their acquired knowledge. Furthermore, the international context asks from every single participant a responsible reflection about cultural, ethical, and socioeconomic issues in regard of the analyzed, compiled and published information. 


\section{The participating schools}

The Geneva School of Business Administration (HEG) offers three major study branches; one of it is Information Science. Following this curriculum, students get an introduction to library, archive and documentation science as well as a deepened knowledge on informatics and its use in the information domain. As a specification within the Information Science branch, which has been offered for more than ten years, students have the possibility to have a third of their courses in German (Geneva School of Business Administration, n.d.). This bilingual education offers its followers a unique possibility to acquire deeper linguistic competences and to get in contact with other German-speaking education institutions within the same branch, by doing, for example, an Erasmus semester (European Commission, 2013). One of these formal Erasmus partnerships has been established with the HdM Stuttgart in 2006 (Stuttgart Media University, 2006).

Stuttgart Media University (HdM) covers a broad spectrum of media expertise: from printed media to electronic media, from media theory to media production, from media design to making media available. The seven-semester degree program, Library and Information Management (Bachelor), combines a long tradition of training in librarianship with the impulses from a dynamically developing world of information and media. The professional research, interpretation and editing of information have as much a place on the syllabus as knowledge of the current media market, enabling the identification of customer-oriented selections of media. Moreover, the degree program offers diverse areas from culture and event management through communication psychology and the educational use of media to the construction of digital libraries. The courses are varied; they include classical lectures, exercises and seminars, workshops and e-learning - partly in the English language (Stuttgart Media University, n.d.).

\section{Assessment method}

The course evaluation has been done on two levels. On one hand, the interactions between instructor and students were analyzed during the entire project duration (12 weeks), using the indicators frequency, and content as well as methodological differences between the two schools. At that time, the exchanges between students were studied by taking into account different processes, which are acknowledged to be signs for high performance teams, explicitly effective communication, positive interrelationships, self-reflection, goal setting, and commitment (Milam, Voorhees

Bedard-Voorhees, 2004; McLoughlin, 2002). For this, students have been qualitatively interviewed by mail at the end of the project about their opinion with respect to it, the encountered difficulties as well as positive outcomes (Tseng, $\mathrm{Ku}$, Akarasriworn, 2013). 


\section{Results}

The following two tables illustrate the compiled results after qualitative data analysis. ${ }^{2}$ The analysis has been done on qualitative mail conversations. The important commentaries can be found after the bibliography. Table I lines up the interactions between instructor and students, whereas Table II gives review of the interactions between students during the project phase.

Table I. Interaction between instructor and students

\begin{tabular}{llll}
\hline & Methodology & Content & Frequency \\
\hline $\begin{array}{l}\text { Stuttgart } \\
(\mathrm{P} 1)^{3}\end{array}$ & $\begin{array}{l}\text { In person, } \\
\text { formal }\end{array}$ & $\begin{array}{l}\text { Answers to students' } \\
\text { questions concerning } \\
\text { problems with platform } \\
\text { and research topic }\end{array}$ & $\begin{array}{l}\text { First theoretical introduction to } \\
\text { project and platform, then regular } \\
\text { (once every second week) }\end{array}$ \\
\hline $\begin{array}{l}\text { Geneva } \\
\text { (P2) }\end{array}$ & $\begin{array}{l}\text { By mail, } \\
\text { informal }\end{array}$ & $\begin{array}{l}\text { Only answers to } \\
\text { students' questions } \\
\text { concerning problems } \\
\text { with platform and } \\
\text { research topic }\end{array}$ & $\begin{array}{l}\text { First theoretical introduction to } \\
\text { project and platform, then } \\
\text { irregular }\end{array}$ \\
& & \\
\hline
\end{tabular}

Table II. Interaction between students

\begin{tabular}{|c|c|c|c|c|c|c|}
\hline & $\begin{array}{l}\text { Effective } \\
\text { communi- } \\
\text { cation }\end{array}$ & $\begin{array}{l}\text { Positive } \\
\text { interrelation } \\
\text {-ships }\end{array}$ & $\begin{array}{l}\text { Self- } \\
\text { reflection }\end{array}$ & $\begin{array}{l}\text { Goal } \\
\text { setting }\end{array}$ & $\begin{array}{l}\text { Commit- } \\
\text { ment }\end{array}$ & $\begin{array}{l}\text { Quality of } \\
\text { final } \\
\text { outcome }\end{array}$ \\
\hline $\begin{array}{l}\text { Group1 } \\
\text { (St 1) }\end{array}$ & Irregular & Yes & Yes & No & Intermediate & Intermediate \\
\hline $\begin{array}{l}\text { Group2 } \\
\text { (St 2, } \\
\text { St 8) }\end{array}$ & Irregular & Yes & Yes & No & Intermediate & Low \\
\hline $\begin{array}{l}\text { Group3 } \\
\text { (St 3, } \\
\text { St 8) }\end{array}$ & Regular & Yes & Yes & No & High & High \\
\hline $\begin{array}{l}\text { Group4 } \\
\text { (St 4) }\end{array}$ & Irregular & Yes & Yes & No & Intermediate & Low \\
\hline $\begin{array}{l}\text { Group5 } \\
\text { (St 5) }\end{array}$ & Regular & Yes & Yes & No & High & High \\
\hline $\begin{array}{l}\text { Group6 } \\
\text { (St 7) }\end{array}$ & Irregular & Yes & Yes & No & High & Intermediate \\
\hline
\end{tabular}

${ }^{2}$ All commentaries may be found at the end of this paper, after the bibliography.

${ }^{3}$ Numbers in parenthesis are student or professor numbers (compare to commentaries at the end of the text).

${ }^{4}$ In this case, « low » means that the students still passed. 


\section{Result discussion}

As it concerns the difference between teacher-student interactions (Table II), students didn't mention a problem with either of the methods. As they were asked to fulfil the task as much on their own as possible, it may be assumed that in this case the method of interaction doesn't play a role, as long as there is the possibility of interaction. Still, due to the already mentioned curricula differences the contributing students from Geneva enter the project with other acquaintances and another problem awareness than the students from Stuttgart. During the interview, students pointed out that they could benefit from each other (see comment 8, 11). As the French-speaking colleagues i.e. knew the dashboard platform better, they explained the different functionalities to the other participants. And they helped them in case of linguistic problems.

Taking a look at Table II, two things seem evident to mention: the organization and effective communication as well as the level of commitment compared to the final outcome.

As a matter of fact, communication seems to be one of the most important, yet most difficult, issues (see comment 2, 10, 13, 14, 15). This goes along with recent findings concerning students' attitudes towards online collaborative learning, where one of the first critical elements mentioned by participants in an online collaborative learning environment is communication (Tseng, Ku, Akarasriworn, 2013).

Students state that the linguistic differences (French-German) are sometimes difficult to handle and imply an often more time-consuming discussion about work objectives than within a single linguistic group. Also, the distance does not always permit effective communication and organization, either because of comprehensive but also technical or simply organizational matters. As the curricula are not the same, it seemed to be sometimes difficult to find a free moment for an online discussion. Furthermore, when conducting a project at the same school, important communications often happens during other courses or "in hallways". Within an online environment, this communication is not possible, which implies that students have to organize themselves differently in order to be able to communicate in an efficient way.

Comparing these results to the quality of the final outcome, a successful method seems to be regular communication (see comment 3,15). One group has chosen a circa 10-day interval as a communication rhythm and organizes the sessions with Skype. The other has established a regular meeting strategy on Facebook. Both of them have a high quality of their final outcome. Evidently, this may be a hazard and further tests are required in order to underline this assumption.

The second most important topic of problems seems to be the team commitment. Comments (see comment 4, 5) of students show that working rhythms don't seem to be the same, which can be interpreted as a low commitment of team members. In the current case, the quality of the final outcome was in both groups with "intermediatelevel"-commitment lower than the others with higher commitment. This may be a question of different working culture or a hazard, but it goes along with Tseng, $\mathrm{Ku}$, Akarasriworn, 2013), who say that team commitment has to be taken seriously into 
account, as it has an impact on participant satisfaction, and it can be assumed, therefore, on project outcome, as well.

Concerning technological communication tools, students were free to choose whatever device they thought to be useful. Results so far show that the most used devices are Mail, followed by Facebook-Chat or Facebook-Group, Dropbox, Skype, and Teamviewer (see comment 3, 9, 12, 17). A student stated that their first choice, Teamviewer, didn't work correctly on the side of the Swiss student. For this reason, they had to start to use Skype (see comment 12). It is interesting to see that the applied communication tools contain not only common one to one writing and chat tools (Mail, Facebook), but also face-to-face communication (i.e. Skype). Even in a non-classroom environment, it seems important to see the face of each other from time to time.

In this case, a student mentioned also the problem of different level of media and information technology literacy (see comment 6). In order to fulfil their task, the concerned student had to motivate and even teach their collaborators to use the concerned tool. Evidently, this means a further implication of the student, but goes perfectly along with the wished outcome of a cooperative learning course (Johnson and Johnson $(1999,2004)$. The student with a high level of computer literacy has to think about teaching methods on distance and in another language, whereas the other one gets new knowledge about online communication tools. Certainly, both of them will benefit of this experience and learn from each other.

Last but not least, students underlined the cultural and professional benefit of the program and are happy to be part of it. They even mention the importance of such an experience for a future work in international environments (see comment 1, 7, 16).

\section{Conclusion}

This paper analyzed and discussed on a micro-level a new course format for LISstudents, which touches all Swiss information literacy standards and shall reinforce students' competence development across boarders and technologies. First of all, the results show that the implementation and conduction of such a comprehensive course format is possible and leads to acceptable, even good results. Furthermore, it apparently offers its participating students a yet challenging experience, which is worth a high quality outcome. Apparently, this form of education really asks students to reflect on communication, collaboration and technological issues, which goes along by the necessity of an education method which prepares for multiculturalism, fast technical developments, and raising obligations to work in teams. This can definitively be seen as a first success of the joint program formula. Still, generalizing conclusions cannot be drawn as the data is few and the course is adapted to a special education environment. 


\section{References}

1. Milam, J., Voorhees, R., Bedard-Voorhees, A. (2004). Assessment of online education: policies, practices and recommendations. In: New directions for community colleges, vol. 126, p. 73-85.

2. McLoughlin, C. (2002). Computer supported teamwork: An integrative approach to evaluating cooperative learning in an online environment. In: Australian Journal of Educational Technology, 18(2), p. 227-254. Retrieved on June 01, 2014 from http://www.ascilite.org.au/ajet/ajet18/mcloughlin.html

3. Ohidy, A. (2009). Cooperative learning methods as preparation for lifelong learning. Retrieved March $\quad 12, \quad 2014 \quad$ from https://www.academia.edu/2014331/Cooperative_learning_methods_as_preparation_for_li felong learning

4. Allen, I.E., Seaman, J. (2007). Online nation: Five years of growth in online learning. Needham, MA: Sloan Consortium.

5. Damon, William/Phelps, Erin (1989). Critical Distinctions among three approaches to Peer Education. In: International Journal of Educational Research, 13, pp. 9-19.

6. European Commission: The ERASMUS Programme - studying in Europe and more (2013). Retrieved on June 01, 2014 from http://ec.europa.eu/education/lifelong-learningprogramme/erasmus_en.htm

7. Geneva School of Business Administration: Bilingual Course Information and Documentation (2013). Retrieved on June 01, 2014 from: http://campus.hesge.ch/id bilingue/bilingue/

8. Johnson, D. W. \& Johnson, R. (1999): Learning together and alone: Cooperative, competitive, and individualistic learning (5th Ed.). Boston: Allyn \& Bacon.

9. Johnson, D. W., Johnson, F.P. (2004). Assessing students in groups: promoting group responsibility and individual accountability. Thousand Oaks, CA: Corwing Press.

10. Ku, H.-Y., Tseng, H. W., Akarasriworn C. (2013). Collaboration factors, teamwork satisfaction, and student attitudes toward online collaborative learning. In: Computers in Human Behavior, vol. 29, p. 922-929.

11. Mergendoller, J. R., Bellisimo, Y., Maxwell, N. L. (2000). Comparing problem-based learning and traditional instruction in high school economics. In: Journal of Educational Research, 93(6), 374-383.

12. Nagy, József (2005). A hagyományos pedagógiai kultúra csdje. In: Iskolakultúra (melléklet), p. 6-7.

13. Ohidy, A (2009). Cooperative learning methods as preparation for lifelong learning. Retrieved June 2014 from http://www.academia.edu/2014331/Cooperative_learning_methods_as_preparation_for_lif elong_learning 
14. Stepanyan, K., Mather, R. and Dalrymple, R. (2013). Culture, role and group work: A social network analysis perspective on an online collaborative course. In: British Journal of Educational Technology, 25 July 2013. doi: 10.1111/bjet.12076

15. Stuttgart Media University: Library and Information Management (2013). Retrieved on June, 01, 2014 from : http://www.hdm-stuttgart.de/bi

16. Stuttgart Media University: Student Exchange with Geneva University (2013). Retrieved on June, 01, 2014 from : http://www.hdmstuttgart.de/view_news?ident=news20061106141505

\section{Comments of students}

1. Comment 1 (Student 1): Sinon l'expérience culturelle était très enrichissante lorsque nous étions à Stuttgart et je me réjouis d'ores et déjà de les recevoir en Suisse!

2. Comment 2 (Student 2): Concernant la collaboration avec Stuttgart, ça va mais il est assez difficile de communiquer et de bien se faire comprendre à distance. Tout prend $2 \mathrm{x}$ plus de temps car il faut sans cesse discuter des consignes. Souvent nous n'avons pas compris la même chose. On arrive toujours à des compromis mais du tout coup [...]

3. Comment 3 (Student 3): Pour moi la collaboration avec les deux étudiantes de Stuttgart se passe très bien. On ajoute régulièrement du contenu sur Netvibes et on en parle ensuite toutes ensemble sur Skype (à peu près tous les 10 jours).

4. Comment 4 (Student 1): Comme mes chers collègues stuttgartiens n'aiment pas vraiment travailler $[\ldots]$ ils n'ont encore rien fait sur le site.

5. Comment 5 (Student 4) : Alors la collaboration va, je tiens quand même à rajouter que je suis plutôt la seule à prendre des initiatives... Mais bon, ça va.

6. Comment 6 (Student 4): Un point quelque peu négatif à souligner pour ce travail, mais je crois qu'il ne s'applique heureusement qu'à mes deux camarades, c'est le manque de connaissances de base en informatique. Ils ne connaissent et ne veulent pas essayer skype (il a déjà fallu les amener à se créer une page sur facebook [...]) et ne sont pas du tout fan de l'utilisation de netvibes [...]

7. Comment 8 (Student 4): [...] J'aurais bien aimé avoir plus d'informations concernant le produit final $[\ldots]$

8. Comment 7 (Student 5): Die Zusammenarbeit [...] verlief zum überwiegenden Teil sehr positiv und hat viel $\mathrm{Spa}$ gemacht $[\ldots]$

9. Comment 8 (Student 5): [...] so gab sie mir nützliche Tipps zur Gestaltung unserer Seite in Netvibes, während ich ihren Text zum Vortrag verbesserte. [...]

10. Comment 9 (Student 5): [...] Die Kommunikation verlief über eine eigens für das Rechercheprojekt, eingerichtete Gruppe in Facebook.

11. Comment 10 (Student 6): [...] Teileweise aufgetretene Probleme sind ausschließlich auf die Sprachbarriere zurückzuführen und konnten in der Regel schnell behoben werden. [...]

12. Comment 11 (Student 6): [...] Die Zusammenarbeit mit einer französischen Muttersprachlerin erlaubte es uns, das Ergebnis des Projekts zweisprachig anzufertigen und so den Kreis für eventuelle Interessenten zu vergrößern.

13. Comment 12 (Student 6): [...] Zur Verständigung ausserhalb der virtuellen Treffen wurde die Nachrichtenfunktion von Facebook verwendet, für die Treffen selbst wurde TeamViewer verwendet. Leider traten bei der Benutzung von TeamViewer technische Probleme bei der Studentin aus der Schweiz auf, die durch die Sprachbarriere nicht geklärt werden konnten, weshalb in einem Fall Skype als Ersatz für TeamViewer verwendet wurde. $[\ldots]$ 
14. Comment 13 (Student 7): [...]Das größte Problem war allerdings Termine zu finden, an denen jeder Zeit hatte. Das war wegen der unterschiedlichen Stundenpläne ziemlich problematisch. [...]

15. Comment 14 (Student 7): [...]Über eine extra erstellte Gruppe bei Facebook haben wir regelmäßig Kontakt gehalten, damit alle auf demselben Stand blieben und jeder wusste, was der andere macht.

16. Comment 15 (Student 8): [...] Die ausschließlich virtuelle Zusammenarbeit war für alle Team-Mitglieder sehr ungewohnt. Kurze persönliche Absprachen wenn man sich zum Beispiel zufällig in der Hochschule trifft, waren nicht möglich. [...]

17. Comment 16 (Student 8): [...] In jedem Fall war diese Form der Zusammenarbeit eine wertvolle Erfahrung. Ich denke auch im Berufsleben kann dies durchaus relevant sein, z.B. wenn man mit Kollegen anderer Bibliotheken zusammenarbeiten will. [...]

18. Comment 17 (Student 8): [...] Die ausgewählten Arbeitsmittel (Facebook, Skype, Dropbox, E-Mail ...) erwiesen sich im Verlauf des Projekts als praktisch und ausreichend. $[\ldots]$

19. Comment 18 (Professor 1): Wir hatten 14-tägig einen Termin, bei dem aber nie alle Gruppen anwesend waren (jeweils nur zwei oder drei Gruppen). An diesen Terminen haben die Gruppen weitgehend selbständig gearbeitet, teilweise mit Skype auch mit euren Teilnehmern synchron. Aber es gab natürlich auch Beratungsbedarf/Fragen an mich. Soweit ich das mitbekommen habe, hatten die anderen Gruppen andere Termine ausgemacht und teilweise auch von zuhause geskypt. 